\title{
PENELITIAN TINDAKAN KELAS (PTK) \\ Meningkatkan Keaktifan Mahasiswa Semester 3 \\ Program Studi Rekam Medik dan Informasi Kesehatan \\ melalui Think-Pair-Share (TPS)
}

\author{
Sri Nawangwulan \\ Sekolah Tinggi Ilmu Kesehatan (Stikes) Yayasan Rs Dr. Soetomo \\ Jalan Karangmenjangan 12 Surabaya
}

\begin{abstract}
Abstrack: Salah satu model pembelajaran untuk usaha peningkatan kemampuan mengajar dosen adalah pembelajaran dengan menggunakan pendekatan struktural dengan tipe Think-Pair-Share (TPS). Pada pembelajaran ini menekankan pada penggunaan struktur tertentu yang dirancang untuk mempengaruhi interaksi mahasiswa mampu lebih aktif dan bekerja sama dengan saling membantu dalam kelompok kecil. Tujuan penelitian ini adalah mempelajari peningkatan keaktifan mahasiswa melalui TPS pada mata kuliah Epidemiologi mahasiswa D3 Rekam Medis dan Informasi Kesehatan STIKES Yayasan RS. Dr. Soetomo Semester 3.

Dari hasil analisis dan pembahasan dapat ditarik kesimpulan bahwa rata-rata keaktifan mahasiswa dilihat dari 10 aspek nilai, 9 aspek meningkat, yaitu keaktifan mahasiswa terhadap jumlah pertanyaan mahasiswa, keaktifan terhadap kualitas pertanyaan mahasiswa, keaktifan mahasiswa terhadap cara mahasiswa menjawab pertanyaan dosen di kelas, keaktifan mahasiswa terhadap kepatuhan mengerjakan tugas meningkat, keaktifan mahasiswa dalam diskusi meningkat, keaktifan mahasiswa terhadap kegiatan kelompok meningkat, keaktifan mahasiswa dalam cara bertanya dan menjawab pertanyaan dalam diskusi juga meningkat, keaktifan mahasiswa dalam melengkapi buku pelajaran epidemiologi tidak meningkat yaitu tetap, perhatian mahasiswa pada keseluruhan jalannya perkuliahan meningkat dan prosentase kehadiran juga meningkat.
\end{abstract}


1. Keaktifan mahasiswa terhadap perhatian mahasiswa pada keseluruhan jalannya perkuliahan meningkat untuk Kelas A sebesar 0,4 dan Kelas B sebesar 0,2 .

2. Keaktifan mahasiswa terhadap prosentase kehadiran meningkat untuk Kelas A sebesar 0,2 dan Kelas B sebesar 0,1.

3. Rata-rata nilai UTS maupun UAS Kelas B lebih tinggi dibanding Kelas A.

Kata kunci: Belajar, Think-Pair-Share, refleksi, keaktifan mahasiswa

Pendidikan merupakan wahana yang penting dalam rangka menciptakan kader-kader bangsa sebagai generasi penerus pembangunan bangsa yang berkualitas. Salah satu tujuan pendidikan adalah membentuk manusia yang baik dan berbudi pekerti luhur menurut cita-cita dan nilai-nilai dari masyarakat serta untuk mencerdaskan kehidupan bangsa. Pendidikan nasional berdasarkan Pancasila bertujuan untuk meningkatkan kualitas manusia Indonesia, yaitu manusia yang beriman dan bertaqwa kepada Tuhan Yang Maha Esa, berbudi pekerti luhur, berkepribadian, berdisiplin, bekerjasama, tangguh, bertanggung jawab, mandiri, cerdas, dan terampil serta sehat jasmani dan rohani dan juga harus mampu menumbuhkan dan memperdalam rasa cinta tanah air dan bangsa.

Pendidikan dipandang sebagai cara yang tepat untuk membentuk sumberdaya manusia yang berkualitas, karena melalui pendidikan manusia mendapat pengetahuan, ketrampilan dan nilainilai sikap sehingga memiliki pola pikir yang sistematis, rasional dan bersikap kritis terhadap masalah yang dihadapi dan mampu bersaing di era global saat ini. Melalui pendidikan manusia dapat mengembangkan dirinya, antara lain melalui proses pembelajaran di sekolah mulai dari sekolah dasar sampai perguruan tinggi, yang masing-masing memiliki visi, misi dan tujuan yang spesifik. 
Menurut Din Wahyudin (Hamdani, mahasiswa, sehingga mahasiswa 2011) mengemukakan bahwa dituntut untuk mampu menguasai pendidikan merupakan usaha materi yang diajarkan oleh dosen. manusia, artinya manusialah yang Penyampaian materi yang mengembangkan makna pendidikan disampaikan oleh dosen harus mampu yang berfungsi untuk kehidupan diserap oleh mahasiswa dengan manusia yang lebih baik. Melalui teknik yang tepat.

pendidikan manusia merubah dirinya Berdasarkan pengamatan tentang sendiri, masyarakat dan negara ke Proses Belajar Mengajar yang arah yang lebih baik.

Bagi negara, pendidikan merupakan investasi peradaban dunia pendidikan, mencetak generasi bangsa yang dilakukan oleh Dosen Mata Kuliah Epidemiologi pada mahasiswa Program Studi D3 Rekam Medik dan unggul sehingga mampu bersaing di Informasi Kesehatan STIKES Yayasan RS Dr. Soetomo Semester 3 era global. Banyak cara yang telah dilakukan oleh manusia agar selama 1 (satu) semester diperoleh hasil sebagai berikut: pendidikan berhasil, salah satunya pendidikan sepanjang hayat atau Long Life Education.

Salah satu teknik pendidikan adalah dengan mengikuti program pendidikan di Perguruan Tinggi. Subyek yang menjadi fokus pendidikan di sekolah adalah

\begin{tabular}{ll}
\hline PENGAMATAN OLEH DOSEN & \multicolumn{1}{c}{ HASIL } \\
\hline $\begin{array}{l}\text { Metode Pembelajaran dengan } \\
\text { Ceramah }\end{array}$ & $\begin{array}{l}\text { Mahasiswa kurang aktif dalam sesi tanya } \\
\text { jawab baik jumlah pertanyaan maupun } \\
\text { kualiatas pertanyaan }\end{array}$ \\
\hline $\begin{array}{l}\text { Metode Pembelajaran dengan } \\
\text { tugas kelompok dan } \\
\text { presentasi (10-11 orang) }\end{array}$ & $\begin{array}{l}\text { Kurang aktif dalam kelompoknya sendiri ; } \\
\text { Kurang aktif dalam menanggapi presentasi } \\
\text { kelompok lain; }\end{array}$
\end{tabular}


Jumlah kelompok terlalu besar;

Kepatuhan mahasiswa dalam mengerjakan tugas kurang;

Cara bertanya dan menjawab pertanyaan dalam diskusi kurang berkualitas;

\begin{tabular}{|c|c|}
\hline Buku-buku referensi & Kurang lengkap \\
\hline $\begin{array}{l}\text { Prosentase } \\
\text { mahasiswa }\end{array}$ & Kehadiran $\quad 70-100 \%$ \\
\hline $\begin{array}{l}\text { Perhatian mahasiswa pada } \\
\text { keseluruhan } \\
\text { perkuliahan }\end{array}$ & $\begin{array}{lccr}\text { Mahasiswa kurang } & \text { perhatian } & \text { pada } \\
\text { keseluruhan jalannya perkuliahan } & \text { dan } \\
\text { beberapa mahasiswa ngobrol sendiri } & \end{array}$ \\
\hline Hasil UTS & Kelas B \\
\hline & Nilai A : 4,9\% \\
\hline & Nilai $A B: \quad 0 \%$ \\
\hline & Nilai B : $29,3 \%$ \\
\hline & Nilai BC: $22 \%$ \\
\hline & Nilai C : $12,2 \%$ \\
\hline & Nilai D : $26,8 \%$ \\
\hline & Nilai E : $4,8 \%$ \\
\hline Prasarana Pembelajaran: & $\begin{array}{l}\text { Cara duduk mahasiswa rapat-rapat karena } \\
\text { bentuk kursi besar, ruang kelas terkesan } \\
\text { sempit }\end{array}$ \\
\hline Pengeras suara & Tidak tersedia di kelas \\
\hline
\end{tabular}

Sesuai masalah tersebut di atas, kemampuan mahasiswa untuk untuk mencapai kualitas pembelajaran melakukan sesuatu yang sifatnya yang tinggi, maka dibutuhkan suatu positif yang pada akhirnya akan metode yang tepat untuk digunakan membentuk life skill sebagai bekal dalam proses belajar mengajar hidup dan penghidupannya. Agar hal mahasiswa. Suatu metode yang tersebut diatas dapat terwujud, dosen menumbuhkan keaktifan siswa dalam proses pembelajaran. Dengan belajar aktif, melalui partisipasi dalam setiap kegiatan pembelajaran, akan terlatih dan terbentuk kompetensi yaitu seyogyanya mengetahui bagaimana cara mahasiswa belajar dan menguasai berbagai cara pembelajaran mahasiswa. Model belajar akan membahas bagaimana 
cara belajar mahasiswa, sedangkan model pembelajaran akan membahas tentang bagaimana cara membelajarkan mahasiswa dengan berbagai variasinya sehingga terhindar dari rasa bosan dan tercipta suasana belajar yang nyaman dan menyenangkan.

Salah satu model pembelajaran untuk usaha peningkatan kemampuan mengajar dosen adalah pembelajaran dengan menggunakan pendekatan struktural dengan tipe Think-PairShare (TPS). Pada pembelajaran ini menekankan pada penggunaan struktur tertentu yang dirancang untuk mempengaruhi interaksi mahasiswa mampu lebih aktif dan bekerja sama dengan saling membantu dalam kelompok kecil.

Dengan melihat latar belakang masalah tersebut peneliti terdorong untuk meneliti masalah tersebut diatas dengan mengambil judul Meningkatan Keaktifan Mahasiswa melalui TPS pada Mata Kuliah Epidemiologi STIKES Yayasan RS Dr. Soetomo Semester 3 Tahun 20132014.

\section{TINJAUAN PUSTAKA}

Model pembelajaran kooperatif tipe TPS dikembangkan oleh Lyman (1985). Menurut Lyman (dalam Arends, 1997 :122) terdapat 3 tahap dalam TPS yaitu thinking, pairing and sharing. Lebih lanjut Lyman (dalam Jones : 2002) menyatakan bahwa langkah-langkah dalam penerapan TPS yaitu :

1. Dosen mengetengahkan suatu permasalahan secara garis besar dan mahasiswa akan menjawab dengan jawaban yang beragam.

2. Dosen memberikan waktu berfikir untuk memikirkan mengenai pertanyaan dari dosen.

3. Kemudian mahasiswa berdiskusi dengan pasangannya, berbagi pendapat, mengklarifikasi dan membandingkan kedua pendapatnya untuk memilih yang terbaik.

4. Tiap pasangan kemudian berbagi gagasan dengan pasangan lain atau dengan seluruh kelas.

Pembelajaran ini memberi kesempatan pada mahasiswa untuk berpikir, menjawab, dan saling membantu satu sama lain dan akan menambah variasi model pembelajaran yang lebih menarik, 
menyenangkan, meningkatkan aktivitas dan kerja sama mahasiswa. Berdasarkan uraian diatas secara garis besar dapat kita ambil kesimpulan, bahwa untuk mencapai keberhasilan pembelajaran Epidemiologi perlu meningkatkan kualitas pembelajaran mahasiswa. Salah satu upaya peningkatan kualitas pembelajaran mahasiswa kita perlu mengganti model pembelajaran konvensional dengan model pembelajaran yang lebih menarik seperti model pembelajaran dengan pendekatan struktural TPS.

Tipe TPS memberikan peluang kepada para mahasiswa untuk dapat mendiskusikan ide-ide mereka miliki dalam rangka menyelesaikan masalah yang disajikan dosen dengan teman dalam satu kelompok. Hal ini sesuai dengan tujuan tipe TPS menurut Lyman yaitu memproses informasi, komunikasi dan mengembangkan cara berfikir.

\section{METODE}

Penelitian ini adalah Penelitian Tindakan Kelas atau Class room Action Research (CAR) dengan jenis deskriptif yang subyek penelitiannya adalah mahasiswa Semester 3 Kelas A dan B sejumlah 81 orang yang dilakukan di Kampus STIKES Yayasan RS Dr. Soetomo pada bulan Nopember - Desember tahun 2013.

Dalam penelitian ini ada beberapa variabel yang diteliti yaitu:

1. Tingkat keaktifan mahasiswa tentang jumlah pertanyaan kepada dosen;

2. Kualitas pertanyaan mahasiswa kepada dosen;

3. Tingkat keaktifan mahasiswa dalam menjawab pertanyaan dosen di kelas;

4. Tingkat kepatuhan mahasiswa dalam mengerjakan tugas kelompok;

5. Tingkat keaktifan mahasiswa dalam diskusi;

6. Tingkat keaktifan mahasiswa dalam kegiatan kelompok;

7. Tingkat keaktifan mahasiswa dalam bertanya dan menjawab pertanyaan dalam diskusi;

8. Tingkat keaktifan mahasiswa dalam kelengkapan buku-buku pelajaran;

9. Tingkat perhatian mahasiswa pada keseluruhan jalannya perkuliahan; 
10. Tingkat kehadiran mahasiswa;

11. Nilai UTS dan UAS

\section{HASIL}

\section{Mahasiswa D3 RMIK (Rekam}

Medis dan Informasi Kesehatan)

Semester 3 berjumlah 41 (empat

puluh satu) orang, terdiri dari 2 (dua)

kelas, Kelas A sejumlah 41 orang dan
Kelas B sejumlah 40 orang. Sasaran

PTK adalah mahasiswa Semester 3

Program Studi D3 RMIK STIKES

Yayasan RS Dr. Soetomo dengan

karakteristik antara Kelas A dan

Kelas B hampir sama, yaitu untuk

Kelas A 39\% laki-laki, dan perempuan $61 \%$, untuk Kelas B $40 \%$ laki-laki dan $60 \%$ perempuan.

Tabel 4.2 Pengamatan Dosen Terhadap Mahasiswa dalam Proses Belajar Mengajar Mata Kuliah Epidemiologi

\begin{tabular}{|c|c|c|c|}
\hline No. & $\begin{array}{c}\text { Pengamatan oleh } \\
\text { Dosen }\end{array}$ & $\begin{array}{c}\text { Sebelum Diterapkan } \\
\text { Metode TPS }\end{array}$ & $\begin{array}{c}\text { Setelah Diterapkan } \\
\text { Metode TPS }\end{array}$ \\
\hline 1 & $\begin{array}{l}\text { Metode Pembelajaran } \\
\text { dengan Ceramah }\end{array}$ & $\begin{array}{l}\text { Mahasiswa tidak aktif } \\
\text { dalam sesi tanya jawab } \\
\text { baik jumlah pertanyaan } \\
\text { maupun kualitas } \\
\text { pertanyaan }\end{array}$ & $\begin{array}{l}\text { Mahasiswa aktif dalam } \\
\text { seksi tanya jawab }\end{array}$ \\
\hline 2 & $\begin{array}{l}\text { Metode Pembelajaran } \\
\text { dengan tugas } \\
\text { kelompok dan } \\
\text { presentasi (10-11 } \\
\text { orang) }\end{array}$ & $\begin{array}{l}\text { Tidak aktif dalam } \\
\text { kelompoknya sendiri; } \\
\text { Tidak aktif dalam } \\
\text { menanggapi presentasi } \\
\text { kelompok lain; } \\
\text { Jumlah kelompok terlalu } \\
\text { besar; } \\
\text { Kepatuhan mahasiswa } \\
\text { dalam mengerjakan tugas; } \\
\text { Cara bertanya dan } \\
\text { menjawab pertanyaan } \\
\text { dalam diskusi; }\end{array}$ & $\begin{array}{l}\text { Lebih aktif dalam } \\
\text { kelompoknya sendiri } \\
\text { Lebih aktif dalam } \\
\text { menanggapi presentasi } \\
\text { kelompok lain } \\
\text { Jumlah kelompok } \\
\text { diperkecil }\end{array}$ \\
\hline 3 & Buku-buku referensi & $\begin{array}{l}\text { Kelengkapan buku-buku } \\
\text { referensi } \\
\text { Kurang lengkap }\end{array}$ & Lebih lengkap \\
\hline 4 & $\begin{array}{l}\text { Prosentase kehadiran } \\
\text { mahasiswa }\end{array}$ & Kehadiran $\%$ & Ada peningkatan $\%$ \\
\hline
\end{tabular}




\begin{tabular}{|c|l|l|l|}
5 & $\begin{array}{l}\text { Perhatian mahasiswa } \\
\text { pada keseluruhan } \\
\text { jalannya perkuliahan }\end{array}$ & Kurang perhatian & Lebih perhatian \\
\hline 6 & $\begin{array}{l}\text { Prasarana } \\
\text { Pembelajaran: }\end{array}$ & $\begin{array}{l}\text { Mahasiswa tidak } \\
\text { memperhatikan materi } \\
\text { yang diajarkan dan ada } \\
\text { yang ngobrol sendiri } \\
\text { - Cara duduk rapat- } \\
\text { rapat bentuk kursi } \\
\text { besar, ruang kelas } \\
\text { terkesan sempit. } \\
\text { - Mic tidak tersedia di } \\
\text { kelas }\end{array}$ & $\begin{array}{l}\text { Mahasiswa lebih } \\
\text { memperhatikan materi } \\
\text { yang diajarkan }\end{array}$ \\
\hline
\end{tabular}

\section{PEMBAHASAN}

Pembahasan pada penelitian ini berdasarkan variable yang diukur yaitu mempelajari peningkatan keaktifan mahasiswa melalui TPS pada mata kuliah Epidemiologi mahasiswa D3 Rekam Medis dan Informasi Kesehatan Semester 3. Sebagaimana hasil penelitian pada Bab 4 jumlah kelompok sebesar 10 kelompok dan aspek yang dievaluasi terdiri dari 10 aspek yaitu aspek 1 Jumlah pertanyaan mahasiswa, aspek 2 Kualitas pertanyaan mahasiswa, aspek 3 Cara menjawab pertanyaan dosen di kelas, aspek 4 Kepatuhan mahasiswa mengerjakan tugas, aspek 5 Keaktifan dalam diskusi, aspek 6 Keaktifan dalam kegiatan kelompok, aspek 7 Cara bertanya dan menjawab pertanyaan dalam diskusi, aspek 8 Kelengkapan buku-buku pelajaran, aspek 9 Perhatian mahasiswa pada keseluruhan jalannya perkuliahan dan aspek 10 yaitu Prosentase kehadiran mahasiswa.

Observasi/pengamatan yang dilakukan oleh dosen pada setiap sesi kuliah dan tanya jawab pada setiap Pokok Bahasan Mata Kuliah Epidemiologi. Kelas A dibagi menjadi 10 kelompok, masing-masing kelompok 4 mahasiswa, kelompok yang terakhir 5 mahasiswa. Kelas B dibagi menjadi 10 kelompok , masing-masing kelompok 4 mahasiswa. Dosen menerapkan metode TPS dengan langkah-langkah yaitu dosen mengetengahkan suatu permasalahan secara garis besar dan 
mahasiswa akan menjawab dengan jawaban yang beragam, kemudian dosen memberikan waktu berfikir untuk memikirkan mengenai pertanyaan dari dosen, dilanjutkan mahasiswa berdiskusi dengan pasangannya, berbagi pendapat, mengklarifikasi dan membandingkan kedua pendapatnya untuk memilih yang terbaik, sehingga tiap pasangan berbagi gagasan dengan pasangan lain atau dengan seluruh kelas.

Setiap memulai kuliah, setelah dosen membuka perkuliahan selalu diadakan pemanasan yaitu mengulang materi minggu lalu dan memberi pertanyaan kepada mahasiswa terkait topik yang akan dijelaskan.

Dosen mengamati hasil pertanyaan sebagaimana daftar dalam kelompok yang sudah dibentuk. Dosen mengamati 10 aspek yang disebutkan di atas. Hasil pada Bab 4 dianalisis secara deskriptif. Dari hasil pengamatan sebagaimana disebutkan pada Bab 4 dirumuskan kemudian menyimpulkan hasil yang diperoleh dari pengamatan selama proses belajar mengajar, sehingga hasil refleksi dapat digunakan sebagai perbaikan terhadap perencanaan yang telah dilaksanakan dan dipergunakan untuk memperbaiki kinerja dosen pada pertemuan selanjutnya. Melalui teknik ini apabila ditemukan adanya kekurangan, maka perencanaan dan pelaksanaan tindakan perbaikan masih dapat dilanjutkan pada siklus berikutnya yaitu pada mata kuliah lain pada semester yang akan datang sampai target yang diinginkan tercapai.

\section{Kajian terhadap Jumlah}

\section{Pertanyaan Mahasiswa}

Jumlah pertanyaan mahasiswa dalam kelompok adalah jumlah pertanyaan yang dikemukakan pada saat dosen menjelaskan materi kuliah epidemiologi setelah Ujian Tenga Semester (UTS) yaitu pada minggu $\mathrm{X}$ sampai minggu ke XV. Jumlah pertanyaan mahasiswa dalam kelompok yang dikemukakan pada saat dosen menjelaskan materi kuliah epidemiologi antara kelas A dan kelas $\mathrm{B}$ hampir sama berkisar antara yaitu 1,6 - 2,1 yang peningkatannya sekitar 0,3 sampai 0,5. Jumlah pertanyaan mahasiswa dalam kelompok berkisar antara 1 sampai dengan 3 pertanyaan. Dosen sudah mengulang-ulang dalam menjelaskan dan dosen sudah 
berupaya mengajukan pertanyaan secara sampling dalam kelompok. Dosen juga berupaya dengan cara agar mahasiswa mengajukan pertanyaan, namun belum bisa optimal. Hal ini kemungkinan disebabkan karena mahasiswa masih belum terbiasa mengajukan pertanyaan, juga karena metoda TPS baru pertama diterapkan. Jika dibandingkan dengan teori TPS, seharusnya mahasiswa lebih aktif dalam mengajukan pertanyaan. Jumlah kelompok ada 10, pengamatan dilakukan mulai pada minggu ke $\mathrm{X}$ sampai dengan minggu ke $\mathrm{XV}$, sehingga waktu yang tersedia juga tidak mencukupi. Keaktifan mahasiswa terhadap Jumlah Pertanyaan Mahasiswa meningkat dari 0,3 dan 0,5 untuk Kelas A dan Kelas B.

\section{Kajian terhadap Kualitas}

\section{Pertanyaan Mahasiswa}

Yang dimaksud dengan

kualitas pertanyaan mahasiswa adalah bobot atau mutu pertanyaan yang diajukan pada dosen sesuai dengan materi yang diajarkan. Kualitas pertanyaan mahasiswa masih terkait dengan jumlah pertanyaan mahasiswa. Kualitas pertanyaan mahasiswa sudah sesuai dengan materi yang diajarkan oleh dosen, namun hasil pengamatan ini baik Kelas A dan Kelas B peningkatannya hampir sama, yaitu Kelas A menunjukkan peningkatan sebesar 0,1 dari skor 2,1 - 2,2 dengan skala cukup. Kelas B meningkat 0,2 dari skor 2,1 - 2,3. Hal ini kemungkinan disebabkan mahasiswa belum terbiasa mengajukan pertanyaan sebagaimana pada butir 5.1 yaitu kajian terhadap jumlah pertanyaan mahasiswa. Kemungkinan juga mahasiswa bertanya karena terpaksa dalam arti daripada tidak bertanya.

Jika dibandingkan dengan teori TPS, jumlah kelompok ada 10, pengamatan dilakukan mulai pada minggu ke $\mathrm{X}$ sampai dengan minggu ke $\mathrm{XV}$, sehingga waktu yang tersedia juga tidak mencukupi. Keaktifan mahasiswa terhadap terhadap Kualitas Pertanyaan Mahasiswa meningkat dari 0,1 dan 0,2 untuk Kelas A dan Kelas B.

Cara Menjawab Pertanyaan Dosen di Kelas

Cara menjawab pertanyaan dosen di kelas adalah keseriusan 
menjawab dalam metode diskusi dan ketepatan benar tidaknya jawaban disesuaikan dengan pertanyaan dosen. Sesuai hasil pengamatan dosen didapatkan bahwa Kelas A dan Kelas B skornya hampir sama berkisar antara 2.0 - 2,5 dengan skala antara cukup dan baik. Hal ini kemungkinan disebabkan karena belum memahami materi yang dijelaskan maupun pertanyaannya, sehingga cara mahasiswa menjawab ada yang yang sudah benar dan ada yang masih salah, artinya cara menjawab ada yang sudah benar dihubungkan dengan pertanyaannya dan sesuai dengan metode diskusi, misalnya ada yang menjawab dengan tertawa atau kurang serius. Jika dibandingkan dengan teori TPS hasil pengamatan dosen pada cara mahasiswa menjawab pertanyaan dosen di kelas, keaktifannya meningkat dari 0,4 dan 0,5 untuk Kelas A dan Kelas B.

\section{Kepatuhan}

\section{Mengerjakan Tugas}

Kepatuhan

mahasiswa mengerjakan tugas adalah kesiapan presentasi kelompok dari tugas yang diberikan dosen termasuk mengumpulkan makalahnya. Sesuai hasil pengamatan dosen didapatkan bahwa Kelas A dan Kelas B Kepatuhan mahasiswa mengerjakan tugas peningkatan skornya berkisar antara 0,2 sampai 0,5. Hal ini terbukti seluruh tugas kelompok yang diberikan kepada mahasiswa semua kelompok siap presentasi dengan power point dan makalahnya dikumpulkan berupa fotokopi makalah dan power pointnya.

Jika dibandingkan dengan teori TPS hasil pengamatan kepatuhan mahasiswa mengerjakan tugas meningkat dari 0,2 dan 0,5 untuk Kelas A dan B.

\section{Keaktifan dalam diskusi}

Keaktifan dalam diskusi adalah keikutsertaan dalam kegiatan diskusi antar kelompok termasuk aktivitas bertanya kepada kelompok lain. Sesuai hasil pengamatan dosen didapatkan bahwa Kelas A dan Kelas B keaktifan dalam diskusi meningkat antara 0,3 dan $0,4 . \quad$ Sebelum diterapkan metode TPS mahasiswa tidak aktif dalam kelompoknya sendiri maupun dalam menanggapi presentasi kelompok lain karena jumlah kelompok terlalu besar. Setelah diterapkan metode TPS yang 
jumlah anggota kelompok diperkecil dari 10 orang menjadi 4 orang, menjadi lebih aktif, sehingga tanggung jawab setiap mahasiswa dalam kelompok semakin jelas dan tidak sekedar ikut dalam kelompok. Kelas A dan Kelas B keaktifan dalam diskusi meningkat antara 0,3 dan 0, 4

\section{Keaktifan dalam Kegiatan}

\section{Kelompok}

Keaktifan dalam Kegiatan Kelompok adalah keikutsertaan dalam mengerjakan tugas kelompok dan presentasi. Sesuai hasil pengamatan dosen didapatkan bahwa Kelas A dan Kelas B didapatkan adanya peningkatan baik Kelas A dan Kelas B yaitu skor 2,0 menjadi 2,5 dan 2,1 menjadi 3,1. Hal ini kemungkinan disebabkan karena mahasiswa sudah terbiasa dengan anggota kelompok besar yaitu 10 orang, sehingga yang penting tugas kelompok sudah ada yang mengerjakan dan siap dipresentasikan. Kenyataan pernah suatu saat presentasi yang mengerjakan tugas belum datang, yang sudah hadir tidak bersedia presentasi. Setiap diskusi dan presentasi kehadiran anggota kelompok lebih dari $75 \%$ hadir atau 3 dari 4 mahasiswa pasti hadir. Keaktifan dalam kegiatan kelompok antara 0,5 dan 1 untuk Kelas A dan Kelas B.

\section{Cara Bertanya dan Menjawab Pertanyaan dalam Diskusi}

Cara bertanya dan menjawab pertanyaan dalam diskusi adalah metode bertanya dan menjawab pertanyaan dalam diskusi kelompok apakah sesuai metode diskusi ilmiah. Sesuai hasil pengamatan dosen didapatkan bahwa Kelas A dan Kelas B cara bertanya dan menjawab pertanyaan dalam diskusi peningkatannya hampir sama yaitu 0,5 dan 0,4, untuk Kelas A 2,0 menjadi 2,5 dan Kelas B 2,2 menjadi 2,6. Semula sebelum diterapkannya metode TPS cara mahasiswa dalam bertanya kepada kelompok lain dalam diskusi kelompok langsung bertanya sendiri tanpa didiskusikan dengan anggota kelompok. Demikian juga dalam menjawab pertanyaan pada saat kelompoknya presentasi dan memberi kesempatan pada kelompok lain untuk bertanya. Cara bertanya dalam diskusi belum sepenuhnya sesuai dengan kaidah diskusi ilmiah, yaitu belum menyebutkan nama, 
kelompoknya, langsung bertanya dan menjawab. Kelas A dan Kelas B dalam cara bertanya dan menjawab pertanyaan dalam diskusi peningkatannya hampir sama yaitu 0,5 dan 0,4 .

\section{Kelengkapan Buku-buku Pelajaran}

Kelengkapan buku-buku pelajaran adalah buku-buku referensi selain materi dari dosen. Skor pada kelengkapan buku-buku pelajaran ini Kelas A dan Kelas B skornya tetap tidak meningkat yaitu 3,0. Hal ini kemungkinan disebabkan karena mahasiswa belum memahami butirbutir evaluasi pada metode TPS yang termasuk di dalamnya kelengkapan buku-buku pelajaran. Mahasiswa sudah terbiasa dengan buku referensi yang dipakai sebelumnya. Kelas A dan Kelas B dalam melengkapi buku pelajaran epidemiologi tidak meningkat yaitu skor 3,0.

\section{Perhatian Mahasiswa pada}

\section{Keseluruhan Jalannya Perkuliahan}

Perhatian mahasiswa pada keseluruhan jalannya perkuliahan adalah kepedulian mahasiswa dalam mengikuti semua kegiatan dalam mata kuliah epidemiologi mulai minggu ke $\mathrm{X}$ sampai dengan minggu
XV. Sesuai hasil pengamatan dosen didapatkan bahwa Kelas A dan Kelas B ada peningkatan skor aspek perhatian mahasiswa pada keseluruhan jalannya perkuliahan sebesar 0,4 dan Kelas B sebesar 0,2 yang hasilnya mencapai skala antara baik dan baik sekali. Hal ini dibuktikan dengan semua aspek yang diamati menunjukkan adanya peningkatan kecuali aspek ke 8 yaitu kelengkapan buku-buku pelajaran.

\section{Prosentase Kehadiran Mahasiswa} Prosentase Kehadiran

Mahasiswa adalah rata-rata kehadiran mahasiswa per kelompok dalam mata kuliah epidemiologi mulai minggu ke $\mathrm{X}$ sampai dengan minggu ke XV. Sesuai hasil pengamatan dosen didapatkan bahwa Kelas A dan Kelas B prosentase kehadiran meningkat 0,2 dan 0,1 dan berada pada skala antara baik dan baik sekali. Rata-rata kehadiran mahasiswa mulai minggu ke $\mathrm{X}$ sampai dengan minggu ke $\mathrm{XV}$ mencapai lebih dari $75 \%$.

\section{UTS dan UAS}

Bila diamati dari nilai UTS didapatkan hasil sebagai berikut, nilai A-AB Kelas B lebih tinggi dibanding Kelas A yaitu sebesar $15 \%$ dan 4,9\%. 
Nilai B-BC Kelas B juga lebih tinggi dibanding Kelas A yaitu 19,6\% dan Kelas A 15\%. Nilai C Kelas B 12,5\% dan Kelas A 12,2 \%. Nilai D-E Kelas A $31,6 \%$ dan Kelas B $20 \%$.

Nilai UAS A-AB Kelas A lebih rendah dari Kelas B yaitu sebesar $19,6 \%$ dan $20 \%$. Untuk nilai
B-BC Kelas A dan Kelas B hampir sama yaitu $58,4 \%$ dan $58,7 \%$. Nilai $\mathrm{C}$ Kelas A sebesar 7,3 \% dan Kelas B $20 \%$, sedangkan nilai D-E Kelas A $14,6 \%$ dan Kelas B 10\%. Rata-rata nilai UTS maupun UAS Kelas B lebih tinggi dibanding Kelas A. 


\section{SIMPULAN}

Dari hasil analisis dan pembahasan dapat ditarik kesimpulan bahwa ratarata keaktifan mahasiswa dilihat dari 10 aspek nilai, meningkat dengan rincian sebagai sebagai berikut.

4. Keaktifan mahasiswa terhadap jumlah pertanyaan mahasiswa Kelas A meningkat sebesar 0,3 dan Kelas B meningkat sebesar 0,5.

5. Keaktifan mahasiswa terhadap kualitas pertanyaan mahasiswa meningkat untuk Kelas A sebesar 0,1 dan Kelas B sebesar 0,2.

6. Keaktifan mahasiswa terhadap cara mahasiswa menjawab pertanyaan dosen di kelas, meningkat untuk Kelas A sebesar 0,4 dan Kelas B sebesar 0,5.

7. Keaktifan mahasiswa terhadap kepatuhan mahasiswa mengerjakan tugas meningkat untuk Kelas A sebesar 0,2 dan Kelas B sebesar 0,5.

8. Keaktifan mahasiswa terhadap diskusi meningkat untuk Kelas A sebesar 0,3 dan Kelas B sebesar 0, 4.

9. Keaktifan mahasiswa terhadap kegiatan kelompok meningkat untuk Kelas A sebesar 0,5 dan Kelas B sebesar 1.

10. Keaktifan mahasiswa terhadap cara bertanya dan menjawab pertanyaan dalam diskusi peningkatannya hampir sama yaitu untuk Kelas A sebesar 0,5 dan Kelas B sebesar 0,4.

11. Keaktifan mahasiswa terhadap melengkapi buku pelajaran epidemiologi tidak meningkat yaitu tetap skor 3,0.

12. Keaktifan mahasiswa terhadap perhatian mahasiswa pada keseluruhan jalannya perkuliahan meningkat untuk Kelas A sebesar 0,4 dan Kelas B sebesar 0,2.

13. Keaktifan mahasiswa terhadap prosentase kehadiran meningkat untuk Kelas A sebesar 0,2 dan Kelas B sebesar 0,1.

14. Rata-rata nilai UTS maupun UAS Kelas B lebih tinggi dibanding Kelas A. 


\section{DAFTAR RUJUKAN}

Arikunto, Suharimi (2010). Prosedur Penelitian Suatu Pendekatan Praktik. Jakarta: Rineka Cipta

Daryanto (2001). Evaluasi Pendidikan. Jakarta: Rineka Cipta

--------- (2009). Panduan Proses Pembelajaran. Jakarta: AV Publisher

Hamdani (2011). Dasar-dasar Pendidikan. Bandung: Pustaka Setia

Huda, Miftahul (2011). Cooperative Learning. Yogyakarta: Pustaka Belajar

Iskandar (2011).Penelitian Tindakan Kelas. Jakarta: Gaung Persada

Rusman (2010).Model-model Pembelajaran. Jakarta: Rajawali Pers

Program Pascasarjana Universitas Airlangga Surabaya (2002). Teknik Penulisan Ilmiah

Sagala, Saiful (2010). Konsep dan Makna Pembelajaran. Bandung: Alfabeta

Sudjana, Nana (2005).Penilaian Hasil Proses Belajar Mengajar. Bandung: Rosdakarya

Supriyono, Agus (2011). Cooperative Learning. Bandung: Pustaka Belajar 
